PUBLIC ENGAGEMENT THROUGH SOCIAL MEDIA: THE SPENDING REVIEW

EXPERIENCE

(*) corresponding author

\author{
Deborah Agostino* \\ Politecnico di Milano, Italy, \\ Department of Management, Economics and Industrial Engineering, \\ Via Lambruschini, 4b, 20156, Milan, Italy \\ e-mail deborah.agostino@polimi.it
}

\author{
Marika Arena \\ Politecnico di Milano, Italy, \\ Department of Management, Economics and Industrial Engineering, \\ Via Lambruschini, 4b,, 20156, Milan, Italy \\ e-mail marika.arena@polimi.it
}

\author{
Giuseppe Catalano \\ Sapienza - Università di Roma, Italy, \\ Department of Computer, Control and Management Engineering “Antonio Ruberti”, \\ Via Ariosto, 25, 00185, Rome, Italy \\ e-mail giuseppe.catalano@uniroma1.it
}

\author{
Angelo Erbacci \\ Politecnico di Milano, Italy, \\ Department of Management, Economics and Industrial Engineering, \\ Via Lambruschini, 4b, 20156, Milan, Italy \\ e-mail angelo.erbacci@polimi.it
}




\section{BIOGRAPHIES OF AUTHORS}

Deborah Agostino, assistant professor at the department of Management, Economics and Industrial Engineering at Politecnico di Milano

Marika Arena, associate professor at the department of Management, Economics and Industrial Engineering at Politecnico di Milano

Giuseppe Catalano, full professor at the department of Computer, Control and Management Engineering “Antonio Ruberti” at Sapienza - Università di Roma

Angelo Erbacci, research assistant at the department of Management, Economics and Industrial Engineering at Politecnico di Milano

\section{SUMMARY}

This paper, relying on three empirical cases of spending reviews carried out in Europe, investigates the social media contribution to engage citizens in spending review processes, the differences between the use of social media (i.e. Web 2.0 tools) compared to traditional Web 1.0 tools in the process of public engagement, finally providing recommendations on how Governments can exploit the potentialities of social media to achieve social legitimacy during spending review processes.

\section{KEYWORDS}

Spending review, social legitimacy, social media, public engagement 


\section{Introduction}

The spending review is a managerial intervention that has been adopted in several European countries, such as Italy, France or UK, especially in the aftermath of the global financial crisis. It can be defined as a process (Agasisti et al., 2015) grounded on the central idea to cut public expenditure based on public sector priorities.

The need to decide about which public services have to be cut and the relative amount of savings represents a crucial issue for citizens, which demands their involvement in order to obtain social legitimacy (Pollitt, 2010). In this context, social media may represent a potential enabling technology for citizens' engagement since extant studies have shown the potentialities of these tools to facilitate dialogue and interaction between citizens and administration (e.g. Bertot et al., 2012a; Vesnic-Alujevic, 2012; Mergel and Bretschneider, 2013).

Against this background, this paper investigates the extent to which social media contribute to public engagement during spending review processes, providing recommendations for Governments on the exploitation of these social technologies. Specifically, we aim to answer the following research question: can Web 2.0 expand public engagement beyond Web 1.0 platforms?

\section{The social dimension of the spending review}

The spending review can be defined as a budget revision process that consists essentially of an analytical evaluation of all the expenses of an organisation (Agasisti et al., 2015). This process is aimed at reducing public spending either by implementing linear or non-linear expenditure cuts based on performance analysis or by re-prioritising expenditures, in order to identify space for new spending proposals or investments. So far, the academic debate has devoted relatively little interest on this theme with the emerging literature describing recent experiences in specific countries or sectors (i.e. Chote et al., 2004; Berry and Sinclair, 2010; Yeates et al., 2011; Niemietz, 2011) or addressing the nature of the spending review process (i.e. Bourgon, 2009; Lapsley and Midwinter, 2010; Monacelli and Pennisi, 2010).

Focusing more specifically on the social dimension of the spending review, one aspect that emerges as being particularly critical is its social legitimacy, intended as citizens' acceptance about the social justice and rationality of the spending review programme (Pollit, 2010). According to Pandey (2010) the difficulties in implementing spending reviews and, more in general, cutback management strategies are indeed related to the 'publicness' of organizations involved, which makes them subject to the influence of their external environment.

Though these concepts of social legitimacy and publicness are deemed as crucial to enact successful spending review processes, in literature no works explicitly investigate the available tools to enhance social legitimacy (i.e. the involvement of citizens and public opinion) and more in general how technology can support public engagement during spending review processes.

In this landscape, we focus particularly on social media (also known as Web 2.0 tools). In this respect, some studies have examined the process of bringing social media into the sphere of Governments, with the aim of providing a roadmap to support their use. These works investigate phases for social media adoption (Mergel and Bretschneider, 2013), policy rules around social media use and associated risks (Bertot et al., 2012a), together with content analysis and sentiment analysis techniques used to extract knowledge from social media data (Sobkowicz et al., 2012; Whitmore, 2012). Other scholars have looked specifically at how central and local Governments exploit social media in public administration activities. Results show that social media are used in knowledge-sharing for managing disasters and critical events (Yates and Paquette, 2011; Kavanaugh et al., 2012), to support politicians (Sobaci and Karkin, 2013), to encourage political participation of citizens (Vesnic-Alujevic, 2012), to increase transparency regarding Government information (Bertot et al., 2012b; Bonsón et al., 2012) and to share information with the public (Agostino, 2013). 
This amount of research on social media only partially tackles the issue of engaging citizens in public decisions, with no evidence about the potential contribution of social media to spending review processes. Extant studies recognise that social media are versatile in encouraging a participatory and citizen-centric interaction between citizens and administrations (e.g. Small, 2012), but without entering into the detail of the level of interactivity achieved, and there is no evidence that their contribution is any better than when using traditional stakeholder engagement tools (i.e. Web 1.0 tools). Moreover, these works do not examine how social media are used in the spending review context for purposes of social legitimisation and public engagement. This study aims at addressing these gaps, by exploring the extent to which Web 2.0 tools contribute towards engaging the public in spending review processes moving beyond Web 1.0 tools.

\section{Conceptual framework}

In order to carry out our study, we framed our analysis along two dimensions, types of web-based instruments and level of public engagement.

\subsection{Types of web-based tools}

Looking at the distinction between traditional web-based tools (i.e. Web 1.0) and social media tools (i.e. Web 2.0), Web 1.0 is typically defined as read-only web (Berners-Lee et al., 1994), thereby static and mono-directional, used to broadcast information from the owner to the community. Web 1.0 tools allow users to search for and read information, with no interactions between the parties and no active participation of the public.

In 2004, Web 1.0 technology progressed towards the next generation of social media, also known as Web 2.0 technologies. These tools are based on the ideas of active participation, connectivity and collaboration (O’Reilly, 2005). Active participation indicates that users can upload contents, photos and videos that may become a source of knowledge for companies and Governments (Chun et al., 2010). Connectivity relates to the virtual network of relationships between users that comes into play even without face-to-face interactions. Collaboration refers to the use of web to share knowledge and ideas in a peer-to-peer network (Schollmeier, 2001).

Yet social media are not a single group of tools, but they comprise a variety of tools based on the abovementioned properties, each of them with their distinctive features. In this study, we investigated social media following the classification proposed by Bonsòn et al. (2012), who distinguished social media on the basis of their interactive features proposing five main categories: blogs, wikis, media-sharing platforms, social networks and micro-blogging.

The list of web-based tools is given in Table 1, with the distinction between Web 1.0 tools and Web 2.0 and a brief description of their functionalities.

$$
<\text { Table } 1 \text {, around here }>
$$

\subsection{Levels of public engagement}

The second element of the framework are the levels of public engagement, defined as the involvement of citizens in public decisions and public life (Rowe and Frewer, 2005). Citizens can be involved in public decisions at different levels (Connor, 1988; Potapchuck, 1991; IAP2, 2007), ranging from information broadcasting by Governments to real-time dialogue. In this paper, we use the classification proposed by Rowe and Frewer (2005), who stated that the flow of information between Government and citizens determines the extent of interaction. This classification proposes three levels of engagement:

- Public communication. This is a one-way information flow, where the information is conveyed from the public administration to citizens, who have a passive role, receiving the information without providing any feedback. 
- Public consultation. This is still a one-way information flow, but in the opposite direction, from citizens to the administration, implying that the public has an active role, commenting on governmental issues.

- Public participation. This is a two-ways information flow with the simultaneous exchange of information between the two parties. It is the highest level of engagement, which generates dialogue between citizens and Governments.

\section{Methodology}

\subsection{Data collection and analysis}

This research was based on a qualitative in-depth analysis of three spending review programmes carried out in three European countries. These were the "Révision Générale des Politiques Publiques" (RGPP) carried out in France from 2007 to 2012, the "Comprehensive Spending Review" (CSR) in the UK in 2010 and the "Processo di revisione della spesa" (PRS) in Italy in 2012. These cases were selected because they concern recent spending review programmes (and therefore can be compared in terms of the development level of Web 1.0 and Web 2.0 tools) and because of the different approaches involved in configuring the process, potentially allowing several engagement strategies to be observed (OECD, 2009).

Data were obtained from two main sources: (1) formal documents, memos, minutes, reports and press releases published by the three Governments; (2) Government websites and social media where interactions between Governments and citizens took place. The source identification followed a snowball approach, so that, moving from the official Government websites, further sources containing spending review information were identified, (e.g. public announcements, press releases, speech transcriptions, legislative texts, official reports and consultation documents) and any item indicating the presence or activity of Governments on social media was explored (e.g. links on Government websites). In parallel, an exploratory analysis of press and blog articles was carried out to identify subsidiary information about public engagement practices used by Governments during spending reviews.

Moving to data analysis, results were categorised according to three main dimensions: the typology of Web 1.0 and Web 2.0 tools, the public engagement level achieved, and the spending review phase during which web-based tools were used. This allowed the authors to track Governments social media use in different phases of their spending reviews, in terms of both content and diffusion, and to analyse the existence of some levels of polarization in connection to the dimensions of the framework.

\subsection{Case setting}

This section introduces the spending reviews implemented in the three countries, following three main phases of the process: framework setting for the spending review, diagnosis of the areas of intervention, final decisions and implementation.

\section{France}

At the end of 2006, the French budget deficit touched 2.5\% of GDP and the debt-to-GDP ratio was about $66.4 \%$. In order to decrease public spending and develop better services, the Government launched a "Révision Générale des Politiques Publiques” (RGPP) in July 2007.

During the framework setting phase, the Government established three different commissions: the Comité de Suivi (CdS), a monitoring committee presided over by the Secretary General of the Prime Minister's office; the Direction Générale de la Modernisation de l'Etat (DGME), a commission with a supporting role presided over by the Minister of Finance; the Comite de Modernisations des Politiques Publiques (CMPP), presided over by the President of the Republic. In the second phase the diagnosis of the areas of intervention - 27 teams of experts analysed public policies and proposed different reform solutions to the CdS, which made a first review. During this phase, the 
Government set up several methods to communicate with the public. The RGPP website acted as the main information portal, providing information concerning the different steps of the review process and publishing the official CMPP reports. In this phase, the DGME introduced an audittype methodology, various analysis of resources and a wealth of expertise to assist in reviewing the existing policies and possible solutions, and in preparing action plans. In the final decision and implementation phase, the CMPP made definitive decisions regarding the various reform solutions and specific interventions. During this phase, each minister was in charge of the interventions within their area of responsibility.

In terms of results, the financial impact of the reforms is difficult to assess. According to some of the official reports published by the French Government (i.e. Assemblée Nationale, 2011) the total savings reached by the end of 2012 was $€ 11.9$ billion.

\section{$U K$}

The "Comprehensive Spending Review" (CSR) began in the UK in 2010 with the objective of making drastic reductions in public spending and deficit, which, at that time, reached the highest levels of recent years (11.0\% of GDP and a debt to GDP ratio of about 59.2\%).

The first phase - framework setting for the spending review - involved publishing a conceptual framework document (HM Treasury, 2010a) that set out the savings targets and the principles to be followed by each department to identify possible cuts. During the second phase, diagnosis of the areas of intervention, several work-groups (composed of civil servants) within each department prepared the proposals. There were also consultations and discussions with the public, using several communication tools, including Web 2.0 tools (such as YouTube, Flickr, etc.). By setting a special on-line application, the Government prompted both public sector workers and the wider public to suggest possible savings and make recommendations. Finally, several groups of experts (composed of both civil servants and external experts) were also involved to review and discuss the proposals. During the last phase of the process - final decision and implementation - the Cabinet examined the proposals and placed the savings within the budgets for the following years.

The spending review identified savings of $£ 81$ billion (about $€ 93$ billion) in departmental expenditure, plus other minor savings in annual management expenditure, that is, spending on welfare benefits, tax credits and pensions (HM Treasury, 2010b).

\section{Italy}

The Italian spending review was introduced in 2012, along with other austerity actions. Similarly to the UK, at the end of 2011, Italy was experiencing a very tricky financial situation, with a budget deficit of $3.9 \%$ of GDP and debt-to-GDP ratio of $120.1 \%$.

The phase of framework setting for the spending review started with the approval of Decree n. 52/2012, which created an inter-ministerial committee with the objective of co-ordinating the entire spending review process. It was composed of the Prime Minister, several other ministers and some external experts with one of the experts being nominated as the Special Commissioner for the spending review. During the second phase of the process, diagnosis of the areas of intervention, the Special Commissioner and Ministry of Finance staff acted separately to identify possible savings. The Government set up a process of public consultation where each citizen could suggest proposals for cuts and savings. The last phase of the process - final decision and implementation - was led by the inter-ministerial committee and subsequently by the Cabinet, which defined the final interventions and inserted them within normative decrees.

The total savings to be achieved by the Italian spending review were about $€ 28.5$ billion over the period from 2013 to 2015.

Table 2 shows the main features of the spending reviews in France, UK and Italy, identifying the phases where public engagement took place. 


\section{Results}

In this section, we discuss the results of the analysis, distinguishing between the types of web-based tools used by the three Governments and the contribution of each tool to public engagement.

\subsection{Web-based tools in spending review experiences}

Table 3 gives an overview of the different web-based tools adopted by Governments for public engagement, with the distinction between social media tools (Web 2.0) and traditional web-based tools (Web 1.0).

\section{$<$ Table 3 around here $>$}

The data shows that all Governments used traditional web-based instruments. These instruments included spending review portals and Government websites. Each Government developed a specific spending review portal, consisting of an ad hoc website presenting the main information about the spending review program and providing data, news and reports about the results achieved. Moreover, each country utilised also the Government website to provide general information on the spending review and to publish official documents regarding its outcomes. For instance, the UK Government provided the majority of information on its spending review on the HM Treasury website, directly publishing some official reports (i.e. HM Treasury, 2010a; 2010b). The use of Web 1.0 tools was quite similar across the three countries. The only difference was the use by the Italian Government of the spending review portal also as a platform where the public could make proposals via e-mail about how to avoid waste and where to concentrate cuts. In this way the spending review portal was utilised as tool to obtain information by citizens. Some 135,000 suggestions were collected in this way.

Only the UK also exploited Web 2.0 tools. The Government adopted media-sharing platforms, social networks and micro-blogging specifically for the spending review process. According to data and information collected, the UK's application of these tools was very rich. Looking at mediasharing platforms, the UK Government used Flickr, posting photos of charts and graphs about the amount of savings and the actual Government expenditure, with about 2,100 hits. The YouTube channel of the HM Treasury posted videos about the phases and the spending review decisions. These videos collected a total of 16,000 hits. Two different social networks were used, Facebook and Dialogue App. The Government's Spending Challenge Facebook page received about 500 comments and 100 likes during the spending review period. The number of people reached by this page was limited: after one week, it had only attracted 70 fans. Paradoxically, an informal Facebook page (“Can this goat get more followers than HM Treasury Spending Challenge?”) was launched with the purpose of collecting more fans than the Spending Challenge Facebook page and received over 1,400 likes. Dialogue App was an ad hoc web application developed by the UK Government to interact with the public and collect feedback, receiving about 100,000 suggestions. Finally, looking at micro-blogging, Twitter reached the highest number of people. HM Treasury Twitter account was used to interact with the public on issues relating to the spending review, with the Government reaching least 103,000 people, these being the number of followers for the HM Treasury at that time.

The UK Government, therefore, made an attempt to embrace an interactive approach based on social media, exploiting different types of Web 2.0 instruments, which cover all the three principles of Web 2.0 technology proposed by O’Reilly (2005). For instance Facebook, Flickr and You Tube clearly tick the box active participation, Twitter that of connectivity and Dialogue App the box of high collaboration among users. However, even if the application of social media was very rich, the diffusion of these instruments resulted low or very low (e.g. Facebook) and shows that the 
Government did not interact with a large number of citizens. On the other hand, the information collected suggests that both Italy and France did not make any effort to introduce social media tools to interact with citizens.

\subsection{Public engagement through social media}

This section discusses the contribution of social media to engage the public in the spending review process. Following our conceptual framework, the section is organised according to different levels of public engagement - public communication and public consultation in particular - whilst public engagement under the form of public participation was not identified in any of the three cases.

$<$ Table 4 around here $>$

Looking at public communication, the approaches adopted by France and Italy are quite similar. The Governments kept the public informed via their official websites and the spending review portals. These tools were used to explain the rationale and the objectives of the spending review, presenting the players involved and the structure of the process. They also had the scope of reporting the main outcomes, such as new reforms and official reports. For instance, the Italian Government uploaded information concerning spending review measures approved by Parliament, such as the abolition of public bodies, new rules for purchasing goods and services and the sale of public buildings. Similarly, the French Government provided information on the different steps of the spending review process and, particularly, in the implementation of the saving programmes by each ministry. In both these cases, communication started at the beginning of the second phase of the process (diagnosis of the areas of intervention) and remained active throughout the third phase (final decisions and implementation). The frequency with which information was posted was quite low, following the timeline of the various steps of the spending review and achievement of results. On average, about eight to ten items of news were posted each month. Compared to this, in the UK, Web 2.0 tools complemented traditional Web 1.0 instruments. Public communication took place over the last two phases of the process but with a higher frequency than for France and Italy, with citizens being updated as things were happening (and not just given the main results). The frequency of information was about one item of news per day. This meant that public communication did not boil down to the publication of official reports and new measures, like in France and Italy, but chronicled the daily "work-in-progress" and the various events (ministers visiting civil servants, announcement of the first measures agreed by ministers).

Moving to public consultation, we found evidence of web tool use only for Italy and the UK. In both cases, public consultation started during the phase of diagnosis of the areas of intervention and was used to identify possible savings and make a better selection of the areas where cuts should be concentrated. Different tools were used in the two cases. In the Italian case, consultation was carried out through the spending review portal (Web 1.0 tool), as discussed in the previous paragraph. Within the portal, a specific page was created presenting the public consultation process, with a standard form for sending suggestions and comments by e-mail. The consultation lasted about one month and received over 135,000 suggestions of savings and remarks about areas or specific sectors in which to implement cuts. All the e-mails were read and forwarded in the form of reports to the decision-makers (the Special Commissioner and the inter-ministerial committee for the spending review). However, the overall incidence of citizen-promoted suggestions was quite low, as was confirmed by the lack of any report detailing which suggestions from the public were included in the final spending review measures. Evidence of this also came from research focusing on the Italian setting (Catalano and Erbacci, 2013). Using Web 2.0 tools, the UK public consultation consisted in an on-line application (Dialogue App), where people could submit ideas, see those of other people and vote for the best suggestions. Information was also gathered using Facebook. The consultation process lasted two months and the UK Government made the commitment to literally take suggestions from the public, forward and implement them, publishing a list of 25 policies that 
originated from such suggestions and making an estimation of their contribution to the total savings resulting from the spending review. Once again, the UK Government seemed more involved in working alongside the public and being more transparent. However, in both Italy and the UK, the public consultation process was attacked, with questions raised about its usefulness and design. An Italian political leader (Beppe Grillo) used his blog to sharply criticise the process of consultation in Italy, seeing it as useless and ineffective (especially for its use of Web 1.0 technologies instead of blogs or other social media). That said, in France, the Government was highly chastised for not having engaged in better public communication and consultation. This had an impact on the implementation of the measures, with loss of trust in Government and the legitimacy of the process, as the spending measures were felt to be imposed and anti-democratic. Therefore, these issues raise the question of how to genuinely listen to citizens and work with them.

\section{Conclusions}

This paper focused on the social legitimacy of spending review processes, by exploring the extent to which the use of social media (Web 2.0 tools) contributes to expand public engagement along the spending review process. To support our investigation, we analysed three cases of spending reviews carried out in France, Italy and the UK. The paper shows that when social media are adopted (as in the case of the UK) the level of public communication and public consultation is higher than when using traditional Web 1.0 tools, and the Government results more involved in working alongside the public. The legitimacy of social media, therefore, clearly appears: Web 2.0 tools enhance the involvement of citizens in political decisions rendering at the same time the action of the Government more transparent. This means that, with respect to Web 1.0 tools, Web 2.0 increase social legitimacy because of the higher involvement of the public. This higher involvement from social media can have potential implications on the spending review outcomes eventually leading to larger public acceptance of the budget cuts and the consequent reduction of the public spending. This empirical evidence provides also the basis for formulating some recommendations on how Governments could exploit the potentialities of Web 2.0 to engage citizens during spending review processes, finally fostering social legitimacy.

First, the potentialities of social media are better exploited during the second phase of the spending review process about the diagnosis of the areas of intervention. It is during this phase, when decisions about the public sector areas involved by the spending review are defined, that dialogue and interactions with citizens are particularly relevant in order to gain social legitimacy. In this context, social media can support a real time consultation and dialogue between Governments and citizens. Although not directly addressed by our empirical analysis, this social media use to foster political participation can impact on the spending review outcomes: boosting the social legitimacy of Government action can indeed increase the success of spending review processes allowing Government to successfully apply the budget cut that have been participatory defined.

Second, once a Government decides to adopt social media to establish dialogue with citizens, then it is necessary to update frequently the social platform, at least daily. Indeed one of the characteristics of social media is the possibility to interact real time, overcoming the offline communication that characterizes Web 1.0 tools. For social media to provide their benefits, ad hoc resources need to be assigned to the continuous update of social platforms, adopting also a language that is not formal, as it could appear on the official website, but closer to a friendly conversation.

Third, once citizens post their comments and opinions on social media, often after an explicit incentive from the Government that posed a specific question, then a reply is necessary for two main reasons. On the one hand, if dialogue wants to be established with citizens, then it is fundamental to provide a reply to the comment from citizens to demonstrate the public commitment towards the adoption of this platform; this approach would improve the possibility that citizens will interact again through social media in the future. On the other hand, a reply to content posted on 
social media is required in order to increase citizens' acceptance about the rationality of the spending review programme.

Finally, the limitations of this work need to be acknowledged. Firstly, this study is based on a qualitative research approach, and the results cannot be considered as generalizable, but they are an analysis of three particular examples that could be representative of different recent approaches to spending review in Europe. Secondly, we relied mainly on documental analysis, focusing on the type of tools used and the impact of these in terms of public engagement. We did not address the problem of exploring the strategic choice made by Governments in connection with the design and use of information obtained from Web 2.0 tools, which opens up the path for future research. Indeed, future works could explore more in depth the motivations at the basis of the choice of using social media for supporting public engagement in spending reviews, and put them in relationship with the use made of the collected information by civil servants. From this perspective, also the national context could be an interesting variable, suggesting the relevance of exploring the influence of local culture in informing social media use for public engagement. 


\section{References}

Agasisti, T., Arena, M., Catalano, G. and Erbacci, A. (2015), International uses and implementations of spending reviews: a proposal for a new comprehensive taxonomy. Public Money and Management, 6(35), pp. 423-430.

Agostino, D. (2013), Using social media to engage citizens: a study of Italian municipalities. Public Relations Review, 39(3), pp. 232-234.

Arena, M. and Arnaboldi, M. (2013), Debate: Dealing with Spending Review - Italy. Public Money \& Management, 33(1), p. 4.

Assemblée Nationale, (2011), Rapport d'information par le comité d'évaluation et contrôle des politiques publiques sur l'évaluation de la révision générale des politiques publiques (RGPP), available at: http://www.assembleenationale.fr/13/pdf/rap-info/i4019.pdf.

Berners-Lee, T., Cailliau, R., Luotonen, A., Nielsen, H.F. and Secret, A. (1994), The World Wide Web. Communication of the ACM, 37(8), pp. 76-82.

Berry, C. and Sinclair, D. (2010), Intergenerational Fairness and the Spending Review 2010, Intergenerational Longevity Centre, London.

Bertot, J.C., Jaeger, P.T. and Hansen, D. (2012a), The impact of polices on government social media usage: Issues, challenges, and recommendations. Government Information Quarterly, 29, pp. 30-40.

Bertot, J.C., Jaeger, P.T. and Grimes, J.M. (2012b), Promoting transparency and accountability through ICTs, social media and collaborative e-government. Transforming Government: People, Process and Policy, 6 (1), pp. $78-91$.

Bonsòn, E., Torres, L., Royo, S. and Flores, F. (2012), Local e-government 2.0: Social media and corporate transparency in municipalities. Government Information Quarterly, 29 (2), pp. 123-132.

Bourgon, J. (2009), Program review: The government of Canada's experience eliminating the deficit 1994-99: A Canadian case study. London: Institute for Government.

Catalano, G. and Erbacci, A. (2013), The diffusion of a budgeting innovation: spending review in situations of financial emergency. In: XXIV riunione scientifica annuale dell'Associazione italiana di Ingegneria Gestionale (AiIG), Milan, 17-18 October 2013.

Chote, R., Emmerson, C., Frayne, C. and Love, S. (2004), Challenges for the 2004 Spending Review, Institute for Fiscal Studies, Briefing Note No. 50.

Chun, S.A., Shulman, S., Sandoval, R. and Hovy, E. (2010), Government 2.0: Making Connections between Citizens, Data and Government. Information Polity, 15 (1-2), pp. 1-9.

Connor, D. D. (1988), A New Ladder of Citizen Participation. National Civic Review, 77(3), pp. $248-257$.

Ferry, L. and Eckersley, P. (2011), Budgeting and Governing for Deficit Reduction in the UK Public Sector: Act One 'The Comprehensive Spending Review'. Journal of Finance and Management in Public Services, 10(1), pp. 14-23.

HM Treasury. (2010a), The Spending Review Framework. Available at http://www.hm-treasury.gov.uk.

HM Treasury, (2010b), Spending Review 2010. Available at http://www.hm-treasury.gov.uk.

Horton, T. and Reed, H. (2010), The Distributional Impact of the 2010 Spending Review, Radical Statistics, 103, pp. 13-24. 
IAP2, International Association for Public Participation. (2007), IAP2 Spectrum of Public Participation. Available at http://www.iap2.org/displaycommon.cfm?an=5

Kavanaugh, A.L., Fox, E.A., Sheetz, S.D., Yang, S., Li, L.T., Shoemaker, D.J., Natsev, A. and Xie, L.X. (2012), Social media use by government: from the routine to the critical. Government Information Quarterly, 29(4), pp. 480-491.

Lapsley I. and Midwinter, A. (2010), Moderniser l'Etat: Les Aspects Financiers des Programme Reviews au RoyaumeUni”, Revue Française D’Administration Publique, 136, pp. 821-835.

Mergel, I. and Bretschneider, S.I. (2013), A three-stage adoption process for social media use in government. Public Administration Review, 73 (3), pp. 390-400.

Monacelli, D. and Pennisi, A. (2010), L’Esperienza della spending review in Italia: problemi aperti e sfide per il futuro, Politica economica, 2, pp. 255-288.

Niemietz, K., (2011), An Analysis of the Welfare Cuts in the Comprehensive Spending Review and the Budget 2010, Economic Affairs, 31(1), pp. 80-85.

OECD (2009), Focus on citizens: Public Engagement for better policies and services. Available at http://www.oecd.org/gov

O’Reilly, T. (2005), What is Web 2.0-Design patterns and business models for the next generation of software. Available at: http://www.oreillynet.com/pub/a/oreilly/tim/news/2005/09/30/what-is-web-20.html.

Pandey, S.K. (2010), Cutback Management and the Paradox of Publicness, Public Administration Review, 70(4), pp. 564-571.

Pollitt, C. (2010), Cuts and Reforms - Public Services as We Move into a New Era, Society and Economy, 32(1), pp. 17-31.

Potapchuk, W. R. (1991), New Approaches to Citizen Participation: Building Consent. National Civic Review, 82(2), pp. 158-168.

Rowe, G. and Frewer, L.J. (2005), A typology of public engagement mechanisms. Science, Technology, \& Human Values, 30(2), pp. 251-290.

Schollmeier, R. (2001), A definition of peer-to-peer networking for the classification of peer-to-peer architectures and applications. In: Proceedings of the 1st International Conference on Peer-to-Peer Computing, pp.101-102.

Small, T.A. (2012), e-Government in the Age of Social Media: An Analysis of the Canadian Government's Use of Twitter. Policy \& Internet, 4(3-4), pp. 91-111.

Sobaci, M.Z. and Karkin, N. (2013), The use of twitter by mayors in Turkey: Tweets for better public services? Government Information Quarterly, 30 (4), pp. 417-425.

Sobkowicz, P., Kaschesky, M. and Bouchard, G. (2012), Opinion mining in social media: modelling, simulating, and forecasting political opinions in the web. Government Information Quarterly, 29 (4), pp. 470-479.

Vesnic-Alujevic, L. (2012), Political participation and web 2.0 in Europe: A case study of Facebook. Public Relations Review, 38 (3), pp. 466-470.

Whitmore, A. (2012). Extracting knowledge from U.S. department of defence freedom of information act requests with social media. Government Information Quarterly, 29 (2), pp. 151-157.

Yates, D. and Paquette, S. (2011), Emergency knowledge management and social media technologies: A case study of the 2010 Haitian earthquake. International Journal of Information Management, 31(1), pp. 6-13. 
Yeates, N., Haux, T., Jaward, R., Kilkey, M. and Timmins, N. (2011), In Defence of Welfare: The Impacts of the Spending Review, Social Policy Association, Available at: http://www.social-policy.org.uk/downloads/idow.pdf. 


\section{APPENDIX}

Table 1. Social media classification

\begin{tabular}{|c|c|c|}
\hline $\begin{array}{c}\text { Type of } \\
\text { technology }\end{array}$ & $\begin{array}{c}\text { Type of } \\
\text { instrument }\end{array}$ & Functionalities \\
\hline Web 1.0 & Websites & $\begin{array}{l}\text { Broadcasting information from the owner to the broader } \\
\text { public }\end{array}$ \\
\hline \multirow{5}{*}{ Web 2.0} & Blogs & Personal diaries that allow users to leave comments \\
\hline & Wikis & Collaborative platforms to create and distribute knowledge \\
\hline & $\begin{array}{l}\text { Media-sharing } \\
\text { platforms }\end{array}$ & $\begin{array}{l}\text { Platforms that allow users to share photos, documents and } \\
\text { videos }\end{array}$ \\
\hline & Social networks & $\begin{array}{l}\text { Applications in which users have their own profile and } \\
\text { interact with other people through messages, photos and } \\
\text { videos }\end{array}$ \\
\hline & Micro-blogging & $\begin{array}{l}\text { Platforms giving users the opportunity of broadcasting } \\
\text { information in the form of a short message, and also interact } \\
\text { and comment on the content published }\end{array}$ \\
\hline
\end{tabular}

Source: Adapted from Bonsòn et al. (2012).

Table 2. The type of spending review in each country

\begin{tabular}{|c|c|c|c|}
\hline & France & UK & Italy \\
\hline Year & 2007 & 2010 & 2012 \\
\hline Context & $\begin{array}{l}\text { Budget deficit: } 2.5 \% \text { of } \\
\text { GDP } \\
\text { Debt/GDP: } 66.4 \%\end{array}$ & $\begin{array}{l}\text { Budget deficit: } 11.0 \% \\
\text { of GDP } \\
\text { Debt/GDP: } 59.2 \%\end{array}$ & $\begin{array}{l}\text { Budget deficit: } 3.9 \% \text { of } \\
\text { GDP } \\
\text { Debt/GDP: } 120.1 \%\end{array}$ \\
\hline $\begin{array}{l}\text { Phases in which } \\
\text { citizens were } \\
\text { engaged }\end{array}$ & $\begin{array}{l}\text { Diagnosis of the areas of } \\
\text { intervention } \\
\text { Final decisions and } \\
\text { implementation }\end{array}$ & $\begin{array}{l}\text { Diagnosis of the areas } \\
\text { of intervention } \\
\text { Final decisions and } \\
\text { implementation }\end{array}$ & $\begin{array}{l}\text { Diagnosis of the areas } \\
\text { of intervention } \\
\text { Final decisions and } \\
\text { implementation }\end{array}$ \\
\hline Savings achieved & About $€ 10$ billion & About $€ 90$ billion & About $€ 30$ billion \\
\hline
\end{tabular}

Source: Authors’ own elaboration. 
Table 3. Types of instruments used

\begin{tabular}{|c|c|c|c|c|}
\hline $\begin{array}{c}\text { Type of } \\
\text { technology }\end{array}$ & $\begin{array}{c}\text { Type of } \\
\text { instrument }\end{array}$ & France & UK & Italy \\
\hline \multirow{3}{*}{$\begin{array}{l}\text { Traditional } \\
\text { web } \\
\text { (Web 1.0) }\end{array}$} & \multirow[t]{3}{*}{ Website } & $\begin{array}{l}\text { Government } \\
\text { website }\end{array}$ & $\begin{array}{l}\text { Government } \\
\text { website }\end{array}$ & $\begin{array}{l}\text { Government } \\
\text { website }\end{array}$ \\
\hline & & $\begin{array}{l}\text { Spending review } \\
\text { portal }\end{array}$ & $\begin{array}{l}\text { Spending review } \\
\text { portal }\end{array}$ & $\begin{array}{l}\text { Spending review } \\
\text { portal }\end{array}$ \\
\hline & & & & $\begin{array}{l}\text { (500,000 hits; } \\
135,000 \text { suggestions) }\end{array}$ \\
\hline \multirow[t]{5}{*}{$\begin{array}{l}\text { Social media } \\
\text { (Web 2.0) }\end{array}$} & \multirow[b]{2}{*}{$\begin{array}{l}\text { Media- } \\
\text { Sharing } \\
\text { platforms }\end{array}$} & & \begin{tabular}{|l} 
Flickr \\
$(2,100$ hits $)$
\end{tabular} & \\
\hline & & & $\begin{array}{l}\text { YouTube } \\
\text { (2 channels; 4videos; } \\
\text { 16,000 hits; } 17 \\
\text { comments) }\end{array}$ & \\
\hline & \multirow[t]{2}{*}{$\begin{array}{l}\text { Social } \\
\text { networks }\end{array}$} & & $\begin{array}{l}\text { Facebook } \\
\text { (100 followers/likes) }\end{array}$ & \\
\hline & & & $\begin{array}{l}\text { Dialogue App } \\
(100,000 \\
\text { suggestions })\end{array}$ & \\
\hline & $\begin{array}{l}\text { Micro- } \\
\text { Blogging }\end{array}$ & & $\begin{array}{l}\text { Twitter } \\
(103,000 \text { followers })\end{array}$ & \\
\hline
\end{tabular}

Source: Authors’ own elaboration. 
Table 4. Level of engagement achieved

\begin{tabular}{|c|c|c|c|c|}
\hline $\begin{array}{c}\text { Level of } \\
\text { engagement }\end{array}$ & $\begin{array}{c}\text { Phase of the } \\
\text { spending review }\end{array}$ & France & UK & Italy \\
\hline $\begin{array}{c}\text { Public } \\
\text { communication }\end{array}$ & $\begin{array}{l}\text { Diagnosis of the } \\
\text { areas of } \\
\text { intervention }\end{array}$ & $\begin{array}{l}\text { Websites } \\
\text { (government } \\
\text { website; } \\
\text { spending review } \\
\text { portal) }\end{array}$ & $\begin{array}{l}\text { Websites } \\
\text { (government } \\
\text { website; } \\
\text { spending review } \\
\text { portal) } \\
\text { Media-sharing } \\
\text { platforms } \\
\text { (YouTube; } \\
\text { Flickr) } \\
\text { Social network } \\
\text { (Facebook) } \\
\text { Micro- } \\
\text { Blogging } \\
\text { (Twitter) }\end{array}$ & $\begin{array}{l}\text { Websites } \\
\text { (government } \\
\text { website; } \\
\text { spending review } \\
\text { portal) }\end{array}$ \\
\hline $\begin{array}{c}\text { Public } \\
\text { consultation }\end{array}$ & $\begin{array}{l}\text { Diagnosis of the } \\
\text { areas of } \\
\text { intervention }\end{array}$ & & $\begin{array}{l}\text { Social network } \\
\text { (Facebook; } \\
\text { Dialogue App) }\end{array}$ & $\begin{array}{l}\text { Website } \\
\text { (spending review } \\
\text { portal) }\end{array}$ \\
\hline
\end{tabular}

Source: Authors' own elaboration. 